\title{
Old Wisdom: Indigenous Democracy Principles as Strategies for Social Change within Organizations and Tribal Communities
}

\author{
Rebecca Maldonado Moore ${ }^{1, *}$ and Thohahoken Michael Doxtater ${ }^{2}$ \\ 1 Facundo Valdez School of Social Work, New Mexico Highlands University, Las Vegas, NM 87701, USA \\ 2 School of Creative Industries, Ryerson University, Toronto, ON M5B 2K3, Canada; mdoxtater@ryerson.ca \\ * Correspondence: rmmoore@nmhu.edu
}

Received: 1 November 2019; Accepted: 10 January 2020; Published: 19 January 2020

check for updates

\begin{abstract}
Community engagement founded on Indigenous decision-making practices is essential in addressing issues during turbulent times and ever-changing political landscapes. Indigenous leaders on this continent were instrumental in practicing democracy to address issues impacting local communities with the people, not in isolation. This paper highlights the Search Conference model as a community based participatory change model with Indigenous principles embedded in the process. Specific cases are presented to demonstrate lessons learned.
\end{abstract}

Keywords: democracy; social change; trauma and resiliency

\section{Introduction}

Community engagement founded on Indigenous decision-making practices is essential in addressing issues in turbulent times and ever-changing political landscapes. Social justice values, democratic decision-making processes, equity and inclusion practices, self-determination principles, and cultural humility compel society to investigate alternative paradigms in achieving successful community engaged outcomes. Considering alternative paradigms is especially true for those working in social services sectors as they navigate macro practice agendas. In community development and with organizations, leaders convene, facilitate, and mediate human interactions where people learn to exercise power for a greater good. Through democratic processes, participation by stakeholders is essential to self-governance. This is especially true in some Indigenous communities where people collectively identify and discuss issues, and recommend solutions.

The authors of this document will be describing an Indigenous approach to strengthen a western participatory action research paradigm when applied to an Indigenous organization or community. The search conference method (Emery and Purser 1996) has been successful engaging across practice settings, with diverse populations, and around the globe in participative planning and development. This systematic planning process gives voice to others in the search for solutions to local issues and problems. A search conference question focuses on given sets of issues or concerns and strives toward collaboratively creating a sustainable plan for the future. The authors have adapted this action research approach, in a structured learning environment, by employing Indigenous community principles and practices while addressing Indigenous issues. Our case examples provide the context for adapting search conferences as well as the Indigenous authors' key lessons learned from these experiences.

Both authors have facilitated organizational and community development projects as action researchers and organizational facilitators in public and private sectors. We have professional and personal experiences exploring and applying Indigenous approaches within the North American continent. We are Indigenous; one U.S., federally recognized and one Canadian First Nations member. 
Our mutual interests in action research, participatory research, and search conferences began in separate but overlapping graduate school programs at an ivy league institution with an existing American Indian Program. We were on Onkwehonwe territory where a confederacy of tribes were/are the original inhabitants of the region. One author facilitated the first search conference in the 30-year history of the Program with the second author facilitating an Iroquois Studies task force as part of the outcomes for this setting. Both authors were intuitively aligned with the idea that ordinary people could identify problems and challenges unique to their situation as well as drive a research process to act on problems through social change efforts. We believe that Indigenous peoples must acknowledge change needs to occur because what had been working was no longer effective. One author immediately recognized the parallel process of the search conferencing and Onkwehonwe ways of problem solving.

In addition, our professional practices include work with mainstream higher education institutions as well as community actions groups with educational and environmental foci in Indigenous communities in the U.S. and Canada. Each action research project was based on optimism: a dream of creating something better; a dream of achieving an action plan process with partners; a dream of co-creating methodological, practical, and theoretical improvements (Greenwood and Levin 1998). For example, one author conducts funerals for his people as practiced in the Kayanerehkowa: The Great Law of Peace (Kayanerehkowa 2018). The other author provides leadership and organizational development services to Indigenous communities and in higher education systems. Thus, our practices frame our theoretical grounding in Action Research (AR) as a community development method and social change process. A disparity in literature addressing Indigenous knowledge models that contribute to Indigenous organizational and community development is evident (Hyland and Noffke 2005; Chino and DeBruyn 2006; Schafft and Greenwood 2003). This document is a vehicle to expand the dialog on the praxis, the benefits, and significant challenges of community based, participatory action research approaches. Doxtater imaginatively calls this subject matter "indigenocracy" whereby there is the practical infusion of Indigenous knowledge of governance in contemporary community development strategies.

A note on Indigenous terms is warranted in this document. The terms "Indians", "American "Indians", "Native Americans", "Indigenous Peoples", and "First Nations" and "aboriginal" are problematic and complex. "Others" constructed these terms to further define rights and benefits of the original inhabitants of given territories or used these terms as footnotes in publications to present Indigenous peoples as subjects. American "Indian" (AI), as is "aboriginal" are legal-political references used in most U.S. and Canadian historical documents that Indigenous peoples use to describe themselves or completely reject (Alfred and Corntassel 2005). A return to tribal specific names or "Indigenous" were developed by Indigenous Peoples over the past 50 years to clearly delineate their unique legal, political, cultural, and moral status within the U.S. and Canada. Therefore, "Indians" are regarded as "distinct political communities possessing inherent rights" (Bird Runningwater 1996, p. 80). These rights include the right to determine who they are through membership criteria, terminology, and related benefits received.

"The variation in particular tribes, customs, philosophies and beliefs is tremendous" (Cajete 1994) among the 573 federal and state recognized American "Indian" bands, villages, and nations across the contiguous United States. There were approximately 2.9 million self-identified Indigenous peoples in the 2010 U.S. Census (U.S. Census Bureau 2012). According to Statistics Canada (2016), there were 634 First Nations or Indigenous communities who are not Métis or Inuit with more than 50 distinct languages (The Canadian Encyclopedia 2019). Within this heterogeneous population, the politics and semantics of who we are, what we are called, and "what we want to be called" are just as diverse. This phenomenon is in part due to degrees of blood quantum established by federal governments; perspectives of "authentic" or traditional "Indians" born and raised on federal reservations or territories with tribal membership; or, "Indians" without tribal membership status. It is important to note that the historical evolution of "Indianism" is dialectical and dynamic reflecting the unique capacity of the original inhabitants to survive within this country. Hence, "others" continued to 
define "Indians" legally through federal treaties and legislation; biologically through blood quantum; culturally through community connections; and politically through tailored tribal membership criteria (Bird Runningwater 1996; Alfred and Corntassel 2005). This lengthy, complex, and oppressive history of defining "Indians" through Euro-American relations continues to occupy courtroom proceedings, Tribal Councils' agendas, city conferences, and even Ivory Towers. Consequently, our names are intricately tied to political identity and all other related Indigenous issues that are beyond the scope of this study (Moore 2002). American "Indian"/Alaska Native, First Nations, Native American, and Indigenous terms in this document are used to describe original inhabitants of bio-regional places.

We offer a brief introduction to action research, participatory action research, and a search conference method. These theories and practices are grounded in a western paradigm that curiously parallels Indigenous ways of knowing. We discuss Indigenous knowledges as well as historical healing as cornerstones for engaged community development. Specific case studies from our professional practices produced outcomes on which we base our assertions in this document. Finally, we conclude with summary remarks on successes and challenges of our Indigenous model.

\section{What Makes Our Work Indigenous?}

Indigeneity, being Indigenous, and responding to colonialism in the U.S. and in Canada is an ongoing conversation. Essentially, cultural ways of life, languages, political-economic circumstances, and place-based connections within post-colonialism sets individuals and Indigenous peoples as communities apart from all others. "Others" have attempted to define Indigenous peoples through socially constructed means, however, Indigenous peoples are remarkably resilient in their efforts to resist colonial structures through their connections to their unique geo-spiritual resources. These resources include tribal/Indigenous creation histories, languages, ceremonies, homelands, and relationships to all of life and people. Indigenous knowledges are based on "collective thinking, being deliberative and as free thinkers capable of innovating, inventing, and adapting to changes facing Indigenous society" (Doxtater 2011b). Furthermore, Indigenous leaders have a responsibility to serve the people and facilitate communications that ensure most, if not all of the people, have their collective needs met. Through praxis, leaders and facilitators navigate complicated landscapes to help others define their issues and problems, asking questions, co-collecting information while assisting in a systematic and democratic decision-making process.

Democracy, in principle and practice, has roots in North America. Indigenous democracy sought solutions to problems by giving everyone a voice, a practice which influenced settler or colonial cultures (Deloria 1998). The Onkwehonwe or the Haudenosaunee political organization had been a living, participatory democracy on a large geographic scale for hundreds, if not thousands of years. Unknown to many non-Indigenous people, the Haudenosaunee political framework influenced the structure of the U.S. Constitution (Lyons et al. 1992). In addition, the Gayaneshakgowa, the Iroquois Great Law of Peace, is based on the principles of peace, leadership, dialog, individual rights, unity, accountability and responsibility to all citizenry. These principles were not published, but were appropriated by the founding fathers of colonial America (Barreiro 1992; Grinde and Johansen 1991; Williams 1999). John Mohawk in (Lyons et al. 1992) states "governments exist for the benefit of all, not the privileges of the few ... the origin of these ideas is clearly rooted in exchanges with the Indians" (p. 71).

As a grass-roots approach to democratizing decision-making, Indigenous peoples have long recognized their individual autonomy; their resistance to colonialism through self-determination; and, their need for collaborative participation in decisions that will impact the entire community (Doxtater 2011b). Through action research, praxis melds theory with action in local issues, local knowledge, and local peoples that produce outcomes to benefit all constituents. Search conferencing promotes a peaceful process in problem solving while recognizing individual rights and the value of democratic dialog. 


\section{Action Research and Participatory Action Research}

Action Research (AR) challenges conventional paradigms by linking theories to practice as a paradigm to inquiry (Reason and Bradbury 2008, p. 1). As an alternative paradigm, the aim of social change is to address practical issues and improve the quality of an organization or a community. AR asserts for sustainable change to occur a given community must share participation in decision-making, in reflection, and in deliberate actions. A community of stakeholders can become co-researchers and co-generators of knowledge focusing on key problems. While imagining what change would look like to address those problems, AR collaborators are engaged in creating action steps that best fit the issues. This process requires systematic cycles of action and reflection to refine further actions with fact-finding resulting in another cycle of research (Lewin 1948). It is through the reflective phases that insight, commitment, and a return to the collective mindset that true transformative change becomes a reality.

Participatory action research, a collaborative method of AR, engages a context-specific community in owning the research process through committed roles as researchers. Each participant is actively involved in designing the research project, data collection and analysis, as well as reporting findings and acting upon those findings. The participants are co-generators and co-learners of knowledge to ensure results are useful and evaluated (Cousins and Earl 1992; Emery and Purser 1996; Greenwood and Levin 1998; Brydon-Miller et al. 2003). As co-generators, local knowledge is valued because the participants live the issues and needs of her or his community. As co-learners, each participant has opportunities to expand their capacity to fully understand the larger, systemic nature of the community issue at hand.

$\mathrm{AR}$ and participatory action research (PAR) evaluation are based on the premise that "local knowledge" is as vital as "expert knowledge" in the design of democratic social change. AR seeks to mobilize that knowledge and help local people articulate themselves so that their local wisdom can be understood. They learn to actively incorporate their knowledge into the evaluation and planning of new actions. The organizational learning environment facilitates both action and reflection. Additionally, empowering stakeholders to have control over their own situation is critical if the outcomes are to be utilized (Sankar 2005; Minkler and Wallerstein 2008; NCAI Policy Research Center and MSU Center for Native Health Partnerships 2012).

\section{Search Conference Methodology}

The search conference (SC) methodological process is grounded in AR, open systems thinking, and educational theories. Argyris et al. (1985) maintain that viable, healthy learning organizations or systems must be open and proactively adaptive to existing and foreseeable environmental factors. By scanning and addressing those cultural, social, and political environmental factors interfacing a system, the actual search conference event facilitates an in-depth analysis of a given system's past, present, and future plans. For example, the Emory-Purser search conference process creates an opportunity to introduce and adapt the Indigenous knowledge concept of grief in general and historical trauma and grief in particular as part of the "past" system analysis. Historical trauma is conceptualized by Dr. Maria Yellow Horse Brave Heart as

a collective complex trauma inflicted on a group of people who share a specific group identity or affiliation-ethnicity, nationality, and religious affiliation. It is the legacy of numerous traumatic events a community experiences over generations and encompasses the psychological and social responses to such events as cited in Evans-Campbell (2008).

Whereas grief is the "normal" process of reacting to loss, individuals can grieve change in the denial-disorientation-discovery pattern. In our professional experiences, both historical trauma and grief must be addressed for change to occur within an Indigenous conferencing context. Infusing Indigenous concepts of healing and dreaming into a search conference process is one strand of this 
study's purpose. More specifically, the Wiping of Tears is a traditional, U.S. northern plains Indigenous healing ceremony that warrants further discussion below.

\section{Search Conference Process}

Conceptualized by Merrelyn Emery, Ronald Purser, and Eric Trist in the 1960s, the search conference is a strategic planning process involving participation to increase responsibility by the local community. Participation is grounded in democratic dialog, open systems thinking, evidence-based practices, "puzzle solving" and a true search for common ground among all stakeholders. The search conference involves professional action researchers or managers from the community to serve as conveners or facilitators of the conference. In theory, skilled facilitators convene, facilitate, mediate human interactions, and posit the locus of control in the local community to find and enact local solutions to locally identified problems using local wisdom and local knowledge. In practice, the skilled search conference facilitator creates a safe-space for stakeholders to collectively identify issues.

The facilitator or co-facilitators separate people from the problems and avoid shaming, blaming, and accusing. They also separate people from their own fears, threats, and worries in order to establish a safe space for reflection, dialog, and action. People will agree on some issues and more likely, will disagree (Doxtater 2011a). Skilled facilitators will mediate interests while simultaneously building consensus. Consensus-building uses purpose-driven participatory processes. This includes all stakeholders because of their significant interest in the learning organization. The open learning community encourages inclusive co-designed and co-generated processes such as learning social research methods together. The facilitator upholds equal access to communications and information as all members set the research agenda and execute the agenda together. The facilitator endorses respect, diverse values, interests, knowledge, and expects mutual accountability.

The purpose of a search conference event is to strategically plan for the Program's future with its stakeholders as a strategy for long-term social change. The aim is to generate collective knowledge that supports the values, ideals, and realities of the total organization or community. This systematic planning process has three distinct stages beginning with Stage I: pre-planning the actual event. Stage II provides structured opportunities to constructively dialog issues and constraints and develop practical plans to facilitate an organization or community's growth. Stage III is the implementation and diffusion phase of search conference activities to ensure a program, agency, organization, or community follows through with its plans for social change. All related stages and activities visually resemble an hourglass shape. As an iterative strategic process, each stage and phase demands stakeholder participation and accountability. Evaluation ensures the process and outcomes are monitored.

Cousins and Earl (1992) noted that organizational learning requires four components to successfully complete a participatory evaluation (PE) process. First, the organization values evaluation. Second, the organization provides the time and resources required. Third, the organization is committed to organizational learning to improve operations. Finally, the stakeholders are motivated and willing to learn new skills (p. 412). The single critical factor for a successful participatory evaluation process is administrative support within the context of political time and space. An administrative structure or a tribal community that acknowledges the existence of socio-political issue(s) and an immediate need to address issues is operating within an effective learning organization framework (Native American Center for Excellence 2012). Table 1 briefly outlines all related activities and processes that generally occur within a full two and $\frac{1}{2}$ day event: 
Table 1. Search conference stages and related activities.

\begin{tabular}{llll}
\hline \multicolumn{1}{c}{ Stage I } & \multicolumn{1}{c}{ Stage II } & \multicolumn{1}{c}{ Stage III } & Post Search Conference Activities \\
\hline $\begin{array}{l}\text { Pre-planning } \\
\text { logistics-off-campus site, } \\
\text { food, lodging }\end{array}$ & $\begin{array}{l}\text { Actual event-strategic } \\
\text { planning process }\end{array}$ & $\begin{array}{l}\text { Implementation and } \\
\text { diffusion }\end{array}$ & $\begin{array}{l}\text { Commitment, resources, participatory } \\
\text { evaluation }\end{array}$ \\
\hline $\begin{array}{l}\text { Existing issue/concerns } \\
\text { discussed with rationale } \\
\text { for search conference } \\
\text { approach dialoged }\end{array}$ & $\begin{array}{l}\text { Environmental } \\
\text { Appreciation, Systems } \\
\text { Analysis, and Integration } \\
\text { of the System and } \\
\text { Environment }\end{array}$ & $\begin{array}{l}\text { All action planning groups } \\
\text { invoke an emergent } \\
\text { process. Specific outcomes } \\
\text { generated from the actual } \\
\text { event and dependent upon } \\
\text { commitment of } \\
\text { individuals. }\end{array}$ & $\begin{array}{l}\text { Administrative and stakeholder } \\
\text { leadership and support }\end{array}$ \\
\hline $\begin{array}{l}\text { Community reference system } \\
\text { using snowball sampling with } \\
\text { invitations to ensure } \\
\text { representative } \\
\text { stakeholders attend }\end{array}$ & $\begin{array}{l}\text { Assess the value and } \\
\text { knowledge of the } \\
\text { individual within the } \\
\text { Program, the existing } \\
\text { system, the interactions } \\
\text { within and among } \\
\text { environmental factors, and } \\
\text { facilitate an action } \\
\text { planning process }\end{array}$ & & $\begin{array}{l}\text { Search conference facilitators following } \\
\text { the event provide an electronic draft } \\
\text { report to all stakeholders for review, } \\
\text { may monitor progress if requested }\end{array}$ \\
\hline
\end{tabular}

Source: Emery and Purser (1996). Search conference. A powerful method for planning organizational change and community action.

\section{An Indigenous Approach to Search Conference Processes}

To recognize power of Indigenous individuals, communities, and organizations, the search conference uses shared knowledge and decision-making processes as the heart of the process and centers the content of AR. Within AR circles, scholars have identified the need to "build more extensively on indigenous knowledge systems" (Alfred 1999; Brydon-Miller et al. 2003; Chino and DeBruyn 2006; Cross et al. 2000; Pyrch and Castillo 2001) as well as identify pre-existing power structures that challenge decision-making and commitment to the cause (Baldwin et al. 2009; Doxtater 2011b; Kristiansen and Bloch-Poulsen 2014; Schafft and Greenwood 2003).

Search conference's applicability with Indigenous groups or organizations is an ideal fit conceptually and methodologically, especially in Stages II and III. The authors teach that democracy is an Indigenous invention that has been adapted to the modern liberal nation state. Ideologically, Indigenous rights, collaboration with Indigenous peoples as participants, democratized decision-making, and researcher responsibilities and ethics are central concerns of developing a culturally appropriate research model for, by, and with Indigenous peoples. Most Indigenous communities already know their problems are complex, involving interrelated cultural, economic, educational, health, historical, legal, political, and social issues. Methodologically, this complexity requires the development of responsible partnerships with Indigenous communities and researchers to address specific problems. Community development models founded on "respect, relevance, reciprocity, and responsibility" for Indigenous peoples and with Indigenous peoples is possible. Examples of effective community-based participatory research models include Minkler and Wallerstein (2008) focus on participatory community development with Indigenous peoples as stakeholders. The SAMHSA "Gathering of Native Americans" (GONA) curriculum for substance abuse community planning and intervention emphasizes healing and transformation (Substance Abuse and Mental Health Services Administration. Gathering of Native Americans 2015). Additionally, the Caldwell et al. (2005) symposium focused on participatory research and program evaluation processes.

Furthermore, recent limited literature supports the value of addressing Indigenous grief in general and historical grief in particular to ensure transformative change occurs (Tuhawai-Smith 1999; Caldwell et al. 2005; Doxtater 2011a; Morelli et al. 2013). The authors provide a focused opportunity to dialogically engage within the contexts and issues facing Indigenous people while planning and implementing innovative community development strategies. Specifically, the authors have applied Indigenous interventions in settings that embrace alternative approaches to democratic decision-making. 
These interventions include a similar process for "talking circles" and the Wiping of Tears ceremony. The talking circle approach simply provides equal voice time to each participant focusing on specific issues, self-reflection, and oral sharing.

The Wiping of Tears is a traditional ceremony within the Lakota Way of Being among U.S. northern Plains tribes. More recently, the Wiping of Tears principles are being applied as a social change process to address "wounds", healing, and transformation. The original Indigenous ceremony facilitates a connection between the mind, body, and spirit especially with the passing of a loved one on the journey to the spirit world. For a period of one year, the family (immediate and/or extended) will cut her/his hair (where the spirit lives) and not participate in social activities but spend time with one another supporting and caring for each other. After the year has passed, the deceased relative's spirit is released to the spirit world in a formal ceremony, with healing songs and with a "give-away" feast. No more tears are allowed to ensure the relative has passed to the spirit world where their deceased relatives are also waiting. It is time to heal. There is celebration and joy in this healing process knowing the living family has honored the memory of the deceased as they return "home".

This traditional Indigenous value and practice could be helpful for Indigenous peoples to wipe away their tears about past injustices within a community or organization. For Lakota tribal unity and spiritual awakening, the Wiping of Tears ceremony was conducted in the annual Bigfoot Memorial Ride that began in 1990 on behalf of the health and happiness of seven generations. The 191-mile horseback ride to Wounded Knee, South Dakota is now in its 25th year. The essential principles of this ceremony have been applied with participants in domestic violence programs, substance abuse programs, correctional facilities, educational settings, and even on U.S. tribal lands addressing environmental justice. Obvious issues and problems within systems begin with talking about those problems and issues. The people recognize and discuss their issues and problems. Healing is built into the dialog allowing everyone to let go of their individual hurt, to make human connections, and if possible, to sing songs of healing and hope. The people then identify community or organizational goals and supporting strategies to achieve those goals. This lengthy process has multiple benefits: self-governance and autonomy are promoted and strengthened. The collective is empowered to sustain positive change through their actions. Additionally, there is a singular focus among all stakeholders in achieving relevant goals.

We make this claim: action research modeled after Indigenous knowledges focuses on a triune that values pragmatism leading to action. In the AR model, a group of people (a) identify a problem (b) pose questions and possible solutions to the problem (c) then decide if they need more research or can take action. This triune is incomplete without accepting that groups of people in the process of coping with change may also be in a conscious or unconscious state of grieving the very change(s) they face.

The authors have seen people exhibit stages of grieving within organizations and institutions. Grieving change can be as trivial as losing your car keys. Denial-disorientation-discovery (DDD) are exhibited as you think "they are here somewhere", followed by "now what do I do", and resolves in "I guess I better call home and get my spare keys". The process is similar and familiar right up to the highest stressor in life-losing a loved one. As researchers familiar with grief as a "normal" process of loss; bereavement involving unique relationships; and complex grief as a delay in experiencing loss, the authors pose that organizational change shows features of grief. The authors describe what happens when people are faced with coping with a loss or change. Individuals and groups react the same way-denial, disorientation, and discovery. In addition, there will always be some element of grief in an organization or a community that is not addressed. As action researchers, we mediate group dynamics in the identification of problems, solutions, and actions. As facilitators, we address unresolved grief or loss to assist in critical self-reflection, learning about resilience in those circumstances and reawakening our individual, Indigenous sense of power; power over our own lives, our families, and our communities. 
We also offer potential additions to AR facilitator toolkits. The extensive use of concept mapping strategies invokes modalities that add to the denial-disorientation-discovery process. We see that the Tuckman (1965) forming-storming-norming-performing theme coincides with our use of collective memory, ideal futures, current realities, and first steps organized by the participants into action groups. In this context, our practices feature a clearly organized methodology by skilled practitioners. Each stage has specific tasks and learning sets for the large and small group processes. As stated above, the purpose of a search conference event is to strategically plan for the Program's future with its stakeholders as a strategy for long-term social change. The event supports group dynamics in their efforts to find commonalities and differences in purpose and to "search" for collective action toward a desired future. The shared learning experiences promotes listening and sharing from each other to become a powerful motivation for subsequent work to carry the effort forward.

The authors seriously consider the serious nature of change or grief. Our action research method uses the search conference method to fully recognize the importance of the unresolved grief. In our experiences of conducting search conference events, we demonstrate how our initial "check-in" session (parallels Stage II, Phase One of the Emory and Purser model) is based on traditional Indigenous practices for grounding participants. We encourage individuals to situate themselves in the initial stages of the Search in a collective memory process in the Wiping of Tears. The participants respond to this check-in exercise in their own words while describing why he/she is participating in the event; what her/his historical knowledge is of the local issues; and, how they have experienced a relationship with the issue, event, or institution. In Stage I: Pre-planning, the authors ensure the right people attending a search conference event is a deliberate course of action. The facilitators of all four of these events provided literature on search conferencing to its members and invited participants beforehand. The literature highlighted the need and rationale for a participatory decision-making process on behalf of the institutions and groups. This is especially true when serving Indigenous communities with specific issues they want addressed, evaluated, or developed into programs.

As Indigenous facilitators, the events begin and end with a traditional, prayer by the facilitator followed by a local community member's prayer and land-acknowledgement statement in Stage II. The participating community member(s) specifically ask their ancestors for assistance in the process (Doxtater 2011a). The participants introduce themselves and have the opportunity to express their expectations and concerns about the search conference process. The next step of the first evening is the group collectively constructs the organization or group's history as a pictorial display of significant events, people, issues, and themes. The purpose of developing a collective history of the issues of importance to individuals is to emphasize the diversity of their experiences and perspectives that contribute to its development. The Wiping of Tears ceremony follows.

We are not proposing that non-Indigenous facilitators cannot achieve successful outcomes in search conferences without prayer or ceremony. Non-Indigenous peoples can probably creatively apply their own ways of bringing the collective to one mind to address their historical issues, losses, and grief. This is part of the power and beauty of action research. Each community or organization is unique, with unique local issues, knowledge, and means of decision-making.

Through these structured steps and phases, the individuals and eventually the collective defines the value and knowledge of the existing systems. All activities are documented, and the content of each section comes directly from the work of the search participants. Wherever possible, the exact wording is recorded on flip charts as groups dialogue and publicly display their work throughout the event. This is in keeping with the philosophy of searching that the local community knowledge, not outside experts, has value and relevance to local needs.

Search conference facilitators reaffirm the following Guiding Principles, Ground-rules, and Rules for Democratic Dialog are in place throughout the entire event and follow up meetings:

- A search is a beginning. The emergent plans at the end of the process require follow-through with commitment by the stakeholders that designed them.

- Active involvement is a given. 
- All participants at the search are equals. Every person is equally important.

- Each person represents her/himself, not the office or status of a particular group.

- Be creative.

- Focus on the future.

- Be open to different ideas.

- Listen to all individuals and ensure everyone has a chance to speak.

- $\quad$ Respect others' ideas.

As the content of the planning process develops at the actual search conference event, the results are often unpredictable since the group itself determines the content of the discussions; non-linear with looping back and repetitions to validate and clarify; and, process-oriented to allow for the generation of discussions and plans with more details. The stakeholders are the people that exclusively determine the general outcomes of the Search. An explicit identification of each participant's role to advance the future planning and actions is a common objective. The stakeholders are ultimately the key to translating the ideas they generate into concrete action. Opportunities to constructively, dialogically engage about issues, constraints, and developing practical plans to facilitate organizational growth are built into Stage II of search conference event phases. Stage III, the implementation and diffusion of search conference activities ensure the groups follow through with its plans for social change.

Three interactive phases structure the second day, Stage II activities that include Environmental Appreciation and THE DREAM followed by a Systems Analysis or AS IT IS, then an Integration of the System and Environment as FIRST STEPS. By the second day, participants have defined the change model and outlined specific action steps needed to operationalize their respective project or program.

The Stage II Phase 2: Systems analysis or AS IT IS process generates a list of "possible activities, events, goals" of the group or organization. Items will emerge from this open dialog as THE DREAM. Each individual is allowed time to share that dream as in a "talking circle" with the larger group framed around her/his personal experience within the group or organization. The next structured activity identifies what the participants viewed as challenges to achieving THE DREAM. Participants are randomly assigned to groups with instructions to discuss commonalities and differences across these challenges. At the end of this brainstorming session, a group representative reports to the entire group a list of the items their group developed with a rationale for each item. Groups report between five and 12 items with consistent themes depending on the context and issues of the group or organization. Search conference facilitators and a few of the group members then integrate the items from these group lists into one master list.

Through this reporting process, search conference facilitator(s) extracts collective future directions. The total group then contrasts the ideal futures list with the AS IT IS items. In Stage II Phase 3, an integration of the system and the environment occurs. This phase focuses on the previously identified future goals that the authors call The Dream and how to begin constructing action plans to implement those goals. The related activities are a continuation of Phase II for each prioritized future goal. Identifying time frames, resources, and constraints, and developing solutions to overcoming obstacles will become part of future smaller group planning sessions. All participants individually volunteer to serve within one of the working committees. The work/action planning committees are instructed that modification of their original plans or directions as a group is acceptable. Each action-planning group establishes their own meeting schedule and agenda among their members. A follow-up search conference meeting is then scheduled over the next few months to monitor progress on committee activities.

Participatory action research is an ongoing process of interactions between the researcher and research participants that allows the examination of Indigenous strengths and emphasizes the use of Indigenous knowledge to address issues (Fisher and Ball 2002a, 2002b). Participatory research and program evaluation processes provide opportunities for Indigenous communities to incorporate "re-traditionalization" into methods. The concept of wraparound services (e.g., interagency services 
addressing emotional, physical, mental, and spiritual needs of the child and family), introduced into the clinical literature in the mid-1980s (Stroul and Friedman 1986), is not a new concept among U.S. Indigenous peoples (Kendziora et al. 2001). Cross et al. (2000) identified a number of re-traditionalization themes inherent in the structures of five out of eight tribal Comprehensive Community Mental Health for Children and their Families programs. Themes included the use of extended family, traditional teachings, culturally specific approaches, and cultural restoration (mentors, crafts, language). Methods were identified that incorporated elders or intergenerational approaches; individual and family skill building for living in two cultures; traditional helping values; and conventional and cultural methods to recognize and treat historic cultural, intergenerational, and personal trauma. Additionally, these programs integrated methods that promote healing of Indigenous identity and self-efficacy; build community connections, culture, group, clan, and extended family; and are based on spiritual beliefs and support systems.

The authors will now present four institutional and tribal community contexts where we facilitated search conferences using our Indigenous approach. We used the generic search conference framework as described above with the addition of prayers, Wiping of Tears (specific to Indigenous trauma and grief), talking circles and consensus building dialog.

\section{Results: Search Conferences Contexts, Issues, and Outcomes}

Each of the community engaged settings presented began with initial conversations with or among individuals of a given setting. All settings with the exception of one classroom at a predominantly white institution had a significant percentage of Indigenous stakeholders. All settings had an informal Indigenous leader or stakeholder that was interested in an innovative approach to strategic planning and requested a search conference to address their situation. As stated above, each context is unique with its local knowledge and a set of concerns or issues within their respective communities. The stakeholders are the ones that set the research question(s) and democratically participate in clarifying the vision, working through the "nightmares" and then taking deliberate action to accomplish specific tasks. Table 2 describes these four (4) contexts that employed Indigenous principles in search conferences.

Table 2. Indigenous search conferences.

\begin{tabular}{|c|c|c|c|c|}
\hline Type & Location & Context & Participants & Outcomes \\
\hline $\begin{array}{l}\text { I US HIGHER } \\
\text { EDUCATION/PRIVATE, } \\
\text { PUBLIC LAND } \\
\text { GRANT (MOORE) }\end{array}$ & USA Northeast & $\begin{array}{l}\text { American } \\
\text { "Indian"/Indigenous } \\
\text { Program with * Land } \\
\text { Grant } \\
\text { Acknowledgment } \\
\text { Statement }\end{array}$ & $n=45$ & $\begin{array}{l}\text { Restructured } \\
\text { program } \\
\text { operations and } \\
\text { services }\end{array}$ \\
\hline $\begin{array}{l}\text { II CANADIAN } \\
\text { HIGHER } \\
\text { EDUCATION/PUBLIC } \\
\text { (DOXTATER) }\end{array}$ & $\begin{array}{l}\text { Mid-central, } \\
\text { southern Canada }\end{array}$ & $\begin{array}{l}\text { Classroom focus on } \\
\text { Murdered and Missing } \\
\text { Indigenous Women * }\end{array}$ & $n=80$ & $\begin{array}{l}\text { Pink Feather } \\
\text { Society; policy } \\
\text { change }\end{array}$ \\
\hline $\begin{array}{l}\text { III CANADIAN } \\
\text { TERRITORY/RESERVE } \\
\text { COMMUNITY } \\
\text { (DOXTATER) }\end{array}$ & $\begin{array}{l}\text { Mid-central, } \\
\text { southern Canada }\end{array}$ & $\begin{array}{l}\text { Classroom focus on } \\
\text { Murdered and Missing } \\
\text { Indigenous Women* }\end{array}$ & $n=12$ & $\begin{array}{l}\text { Pink Feather } \\
\text { Society; policy } \\
\text { change }\end{array}$ \\
\hline $\begin{array}{l}\text { IV US HIGHER } \\
\text { EDUCATION/PUBLIC } \\
\text { (MOORE AND } \\
\text { DOXTATER) }\end{array}$ & USA Southwest & $\begin{array}{l}\text { American } \\
\text { "Indian"/Indigenous } \\
\text { Program * }\end{array}$ & $n=18$ & $\begin{array}{l}\text { Designed and } \\
\text { implemented new } \\
\text { program } \\
\text { operations and } \\
\text { services }\end{array}$ \\
\hline
\end{tabular}

* All higher education institutions have Land Acknowledgement statements.

\subsection{U.S. Higher Education/Private, Public Land Grant Institution}

An Ivy League, land-grant institution evolved on Indigenous territory on appropriated land over a century ago. Two diverse cultures gave rise to what is now one of the most prestigious American "Indian" Programs (AIP) in the country. Hundreds of individuals have contributed to the Program as it 
is today, however there was a definitive leadership era through the 1990s that restructured the Program into a viable organization. Leadership, political timing, an engaged critical mass, and a collective vision drove this movement.

As a graduate student during this time, and as a community organizer by profession, Moore knew that the AIP was operating under complex challenging institutional and community issues. Overall, these issues were about distributive justice or remedying systemic injustice. The AIP was politically and academically relegated to an historical building with minimal resources. After discussing these systemic challenges with the then Tuscarora Program Director, she agreed that a search conference would be in the best interest of the floundering program. Institutional politics had been defining what the program could or could not be. In support of self-determination, most of the stakeholders became "one mind" in assessing and redirecting its value and services.

Through a 2.5-day search conference process, the stakeholders addressed focused questions to drive the restructuring process. How can Indigenous peoples and higher education systems engage in a co-determined, collaboratively planned development of programs meet the needs of stakeholders while taking advantage of the best resources higher educational institutions can offer? What is the quality and effectiveness of the AIP in meeting the needs of a diverse constituency? Additionally, how can the Program be improved? Over three years with multiple follow up meetings, the AIP answered these questions and emerged with a plan that included developing the academic component, administratively restructuring, expanding recruitment and retention services, developing outreach goals, proposing an Iroquois Studies program, and strengthening resource generation linkages and commitments.

\subsection{II and III. Canadian Higher Education/Public}

Doxtater's expertise in organizational learning enacted student-centered and client-centered principles. An opportunity to teach student governance and group facilitation was created in his work with an Aboriginal Institute (the Canadian version of a U.S. tribal college) delivering programs through articulation agreements with two mainstream institutions. In this environment, Doxtater put theory into practice. The story of the Pink Feather Society reiterates our joint postulate about putting the client-centered theory into practice.

In the liberal arts course Doxtater taught at the Aboriginal Institute, his focus was on Indigenous issues. Indigenous students provided three group presentations on murdered and missing Indigenous women (MMIW). In 2015, a Canadian national debate was critical of then Prime Minister Stephen Harper's government stand that MMIW was a policing matter. During these sessions, Doxtater took a pink-plume and pinned it to his lapel. Intrigued, students asked where he got it. "I made it". The students asked if they could use the pink feather in a campaign to draw attention to MMIW. During the same time, Doxtater's mainstream university students also had group presentations that focused on MMIW. Only two of the 80 university students were of Indigenous ancestry. They also expressed alarm at Prime Minister Harper's stand.

As background to these courses, these distinct groups of students, were also students in separate classes in the winter semester of 2015. The first predominantly white institution class was titled Indigenous Community Organizing. The second predominantly white institution (PWI) class was Group Facilitation. The second group of Indigenous students had specific plans for the Pink Feather Society. Their main project would be to facilitate a group to help with their project-to draw attention to MMIW and support the surviving children. The PWI Indigenous (Aboriginal) college students proposed that the PWI university students collaborate with them in their Pink Feather Society which they agreed to.

The work began with a strategic action planning workshop—what the author called a "mini-search". The students created teams for events planning, communication, fund raising, and the Pink Feather Promise (see https://www.facebook.com/Pink-Feather-Society-640274739452705/). Nearly 90 students gathered for a workshop, what became known as the Pink Feather Society, with a mission to create a fund to support the education of MMIW's children. The catalogue of accomplishments demonstrates what Ira Shor described that can be accomplished When Students Have Power (Shor 1996). The students 
held a protest march on the Sunday of International Women's Day; organized flash mobs in malls and in local communities; organized bake sales; and, created merchandise. Media attention grew. The students also received a certificate from MPP Dave Levac, the Speaker of the House in Ontario provincial legislature. In the end, a change in the federal government also saw a change in policy that created the federal judicial inquiry into MMIW and girls. In 2016, the Pink Feather Society presented their first bursary to an Indigenous student. The author's role as their faculty advisor was to ensure their due diligence in conducting their affairs. They worked for social justice, something that is a foundational principle for professionals in the social service sector. The students also complied with academic requirements for learning about group facilitation, mediation, social enterprise, and social service. Both authors pose that the social justice subtext is inherent in our practices. We do not educate people about social justice in teaching and counselling. We do social justice. A basic premise of the AR method—big do, little talk.

\subsection{U.S. Higher Education/Public, Comprehensive State Institution}

Applying our experience to a southwestern university's plan to create an Indigenous knowledge center was a focus in our work over the past few years. In the heart of "Indian" country, known for their cowboy mascot, this small comprehensive university in the southwestern region of the United States is located on the ancestral territories of multiple Indigenous nations. As a Hispanic Serving Institution, the majority of tenure/tenure track faculty are non-ethnic minorities. There was one Indigenous faculty member; the majority of all students were racially and culturally diverse (64\%); and approximately 7.3\% self-identified as Indigenous (New Mexico Highlands University Institutional Factbook 2016). The administrative structure had been aware of these historical inequities for years yet never addressed the lack of diversity or cultural representation among stakeholders.

In 2009, the former, interim dean of the School of Social Work revisited the school's dated mission statement. The mission statement was revised to include the school's efforts "to serve Hispanic and Native American people". By 2015, the then university provost directed a national search to recruit Indigenous faculty with an express charge to create a program that would recruit and retain "Indian" students and faculty. Moore accepted her duties as a faculty member and as the Coordinator of this new initiative in September 2015. She established the Indigenous Knowledge Center (IKC) Steering Committee to draft preliminary vision and mission statements and goals consistent with the school's master plans. These initial discussions proceeded with hosting a search conference event in spring 2016. Both authors facilitated this strategic planning process and integrated Indigenous interventions in all phases of the event. The search conference question was How can we create the highest quality Indigenous Knowledge Center to develop and provide leadership, knowledge and service? The Indigenous Knowledge Center community development model was a stakeholder generated, student-centered, and engaged learning process focusing on undergraduate and graduate students specific to the social work profession. However, other curricular and co-curricular units became actively engaged in the initial set of goals. The Indigenous Knowledge Center search conference yielded five strategic working committees committed to Inclusion, Mentorship and Recruitment, Curriculum, Research, and Strategic Planning and leadership.

\section{Conclusions: Key Issues and Recommendations}

Most Indigenous peoples value spiritual teachings and practices as a means to living a balanced life. Prayer personally sustains us and is essential in sustaining our professional lives. Although there is a "separation of church and state" in the U.S., we are still guaranteed the freedom to practice any religion of choice. We intentionally brought prayer to our search conference venues to establish a spiritual element before, during, and after our strenuous decision-making processes. Valued and respected elders were invited to participate and bless the processes to ensure good outcomes were generated. We are resilient and know where we came from and who we are as sovereign nations and 
spiritual beings. These foundational principles are inherent in Indigenous group decision-making processes of which search conferences are one model for facilitating stable social change.

Returning to Cousins and Earl (1992) comments on stakeholder participation and organizational learning, we came through our search conference processes with significant insights. Our findings were premised on group facilitation dynamics and leadership skills. The creation and completion of outcomes resided within the context of the ethical facilitator-sharing assumptions while resisting presumptions. Valued actions and outcomes of search conference processes include:

1. planning and evaluation;

2. making every attempt to collectively develop blue prints for change;

3. ensuring safety in dialog for community input;

4. committing to diverse, representative interests;

5. including students, staff, and community members in developing activities; and,

6. ensuring we had the relevant stakeholders in the group work rooms.

However, as ethical facilitators, we posit the locus of control in the local community (Freire 1970). Additionally, as Alinsky (1989) would say, status-quos will not move until faced with their community. We assembled groups of people to develop and create dialogically engaged processes to operationalize projects or programs. Collective blue prints were developed to serve the people in their respective communities or organizations. Developing and sustaining these blue prints rests on the shoulders of those within the community or organization.

The search-for-solutions is an Indigenous facilitation process that has been historically practiced within Indigenous communities over generations. Clearly, our research shows the need for discussion and unity when addressing issues that impact all citizens of a given tribe, community, or organization. This process often entails difficult conversations with numerous opinions about topics based on lived experiences.

Intergenerational and historical grief and trauma are experiences among most Indigenous peoples and communities. For those individuals that recognize how the grief issues have impacted him or her, they are searching for their own "truth and reconciliation" in order to become balanced beings. They want to serve others and know that she or he cannot be effective without addressing personal issues first. The ripple effect is that these individuals become the champions of social change, wanting the best for themselves, their children and families, and their communities-but most importantly for their Indigenous futures. Skilled Indigenous leaders can facilitate productive discussions that eventually lead to decisions that benefit most, if not all members.

The issue of inclusion is always an important principle in democratic decision-making. All stakeholder groups should be represented and have a voice in the process. Besides, in most Indigenous communities, members "vote with their feet". If they want to participate, they will offer their voice and respectfully listen to the opinions of others. Building respectful relationships can result in successful collaborations that ultimately produce successful outcomes.

Sustainability of outcomes is always an issue. When dialoging the infrastructure of some Indigenous governing body or community organizations, the lack of fiscal resources is generally stated. The search-for-solutions is not always about financial resources or "deep pockets". Administrative or organizational support is critical. However, stakeholder's values and beliefs about a given issue sustains the projects or programs over time. Commitment to those values is what programs need to ensure expanding the circle of support. Additionally, those resulting task force groups that are identified in search conference processes can enact long-term projects with lives of their own. Thus, praxis.

Author Contributions: Both authors contributed to the conceptualization of this manuscript following the southwestern higher education search conference that we co-facilitated. R.M.M. developed the methodological process, including visuals, and drafted the original manuscript. The writing, reviewing, analysis, and editing processes was shared work. R.M.M. maintained the data curation. All authors have read and agreed to the published version of the manuscript. 
Funding: This research received no external funding.

Conflicts of Interest: The authors declare no conflicts of interest.

\section{References}

Alfred, Taiaiake. 1999. Peace, Power, Righteousness: An Indigenous Manifesto. Toronto: Oxford University Press. Alfred, Taiaiake, and Jeff Corntassel. 2005. Politics of Identity-IX: Being Indigenous: Resurgences against Contemporary Colonialism. Government and Opposition 40: 597-614. [CrossRef]

Alinsky, Saul. 1989. Rules for Radicals. A Practical Primer for Realistic Radicals. New York: Vintage Books.

Argyris, Chris, Robert Putnam, and Diana Smith. 1985. Action Science. San Francisco: Jossey-Bass Publishers.

Baldwin, Julie A., Jeannette L. Johnson, and Christine C. Benally. 2009. Building partnerships between Indigenous communities and universities: Lessons learned in HIV/AIDS and substance abuse prevention research. The American Journal of Public Health 99: S77-S82. [CrossRef] [PubMed]

Barreiro, Jose, ed. 1992. "Indian" Roots of American Democracy. Ithaca: Akwe:kon Press.

Bird Runningwater, Niles. 1996. Exploring ethnic fraud: An analysis of verification policies for American Indians in higher education. Master's thesis, University of Texas, Austin, TX, USA.

Brydon-Miller, Mary, Davyd Greenwood, and Patricia Maguire. 2003. Why action research? Action Research 1: 9-28. [CrossRef]

Cajete, Gregory. 1994. Look to the Mountain. Durango: Kivaki Press.

Caldwell, Joyce Y., Jamie D. Davis, Barbara Du Bois, Holly Echo-Hawk, Jill S. Erickson, R. Turner Goins, Calvin Hill, Walter Hillabrant, Sharon R. Johnson, Elizabeth Kendall, and et al. 2005. Culturally competent research with American "Indians" and Alaska Natives: Findings and recommendations of the first symposium of the work group on American "Indian" research and program evaluation methodology. American Indian and Alaska Native Mental Health Research: The Journal of the National Center 12: 1-21. [CrossRef] [PubMed]

Chino, Michelle, and Lemyra DeBruyn. 2006. Building True Capacity: Indigenous Models for Indigenous Communities. The American Journal of Public Health 96: 596-99. [CrossRef] [PubMed]

Cousins, J. Bradley, and Loma M. Earl. 1992. The case for participatory evaluation. Educational Evaluation and Policy Analysis 14: 397-418. [CrossRef]

Cross, Terry L., Kathleen Earle, Holly S. Echo, and Kathryn Manness. 2000. Cultural Strengths and Challenges in Implementing a System of Care Model in American "Indian" Communities. Systems of Care: Promising Practices in Children's Mental Health, 2000 Series; Washington, DC: U. S. Department of Education Educational Resources Information Center, ED 467100, pp. 421-23.

Deloria, Philip J. 1998. Playing "Indian". New Haven: Yale University Press.

Doxtater, Thohahoken M. 2011a. Healing historical unresolved grief: A decolonizing methodology for Indigenous language revitalization and survival. ALAR: Action Learning and Action Research Journal 17: 89-108.

Doxtater, Thohahoken M. 2011b. Putting the theory of Kanataron:non into practice: Teaching Indigenous governance. Action Research 9: 385-404. [CrossRef]

Emery, Merrelyn, and Ronald E. Purser. 1996. Search Conference. A Powerful Method for Planning Organizational Change and Community Action. San Francisco: Jossey-Bass Publishers.

Evans-Campbell, Teresa. 2008. Historical trauma in American “Indian"/Native Alaska communities A multilevel framework for exploring impacts on individuals, families, and communities. Journal of Interpersonal Violence 23: 316-38. [CrossRef] [PubMed]

Fisher, Philip A., and Thomas Ball. 2002a. Redefining the relationship between researchers and American "Indian"/Alaska Native communities: Native American postcolonial participatory action research. Manuscript submitted for publication.

Fisher, Philip A., and Thomas Ball. 2002b. The "Indian" Family Wellness project: An application of the tribal participatory research model. Prevention Science 3: 233-38. [CrossRef] [PubMed]

Freire, Paulo. 1970. Pedagogy of the Oppressed. Chapter 1. Available online: https://selforganizedseminar.files. wordpress.com/2011/08/freire_pedagogy_oppresed1.pdf (accessed on 1 November 2019).

Greenwood, Davyd J., and Morton Levin. 1998. Introduction to Action Research. In Social Research for Social Change. Thousand Oaks: Sage Publications.

Grinde, Donald A., Jr., and Bruce E. Johansen. 1991. Exemplar of Liberty: Native America and the Evolution of Democracy. Los Angeles: American "Indian" Studies Center. 
Hyland, Nora E., and Susan E. Noffke. 2005. Understanding diversity through social and community inquiry. An action-research study. The Journal of Teacher Education 56: 367-81. [CrossRef]

Kayanerehkowa. The Great Law of Peace. Available online: http://www.ganienkeh.net/thelaw.html (accessed on 16 January 2018).

Kendziora, Kimberly, Eric Bruns, David Osher, Debra Pacchiano, and Brenda Mejia. 2001. Wraparound: Stories from the Field. Systems of Care: Promising Practices in Children's Mental Health, 2001 Series; ERIC Number: ED470528; Washington, DC: U. S. Department of Education Educational Resources Information Center.

Kristiansen, Marianne, and Jørgen Bloch-Poulsen. 2014. Power and contexts: Some societal conditions for organizational action research-Clashes between economic-management and pedagogic-social discourses. International Journal of Action Research 10: 339-75.

Lewin, Kurt. 1948. Action Research and Minority Problems. In Resolving Social Conflict. Edited by Gertrud Weiss Lewin. New York: Harper \& Row, pp. 201-16.

Lyons, Oren, John Mohawk, Vine Deloria Jr., Laurence Hauptman, Howard Berman, Donald Grinde Jr., Curtis Berkey, and Robert Venables. 1992. Exiled in the Land of the Free: Democracy, "Indian" Nations, and the U.S. Constitution. Santa Fe: Clear Light Publishers.

Minkler, Meredith, and Nina Wallerstein. 2008. Community-Based Participatory Research for Health: From Process to Outcomes, 2nd ed. San Francisco: Jossey-Bass.

Moore, Rebecca Marie. 2002. Akwe:kon in Mohawk Means All of Us. Ph.D. thesis, Cornell University, Ithaca, NY, USA.

Morelli, Paula T., Peter J. Mataira, and C. Malina Kaulukukui. 2013. Indigenizing the curriculum: The decolonization of social work education in Hawaii. In Decolonizing Social Work. Edited by Mel Gray, John Coates, Michael Yellow Bird and Tiani Hetherington. New York: Routledge, chp.10. pp. 207-22.

Native American Center for Excellence. 2012. Steps for Conducting Research and Evaluation in Native Communities. 2014. Available online: https://www.samhsa.gov/sites/default/files/nace-steps-conductingresearch-evaluation-native-communities.pdf (accessed on 18 January 2018).

NCAI Policy Research Center and MSU Center for Native Health Partnerships. 2012. 'Walk Softly and Listen Carefully': Building Research Relationships with Tribal Communities. Washington, DC and Bozeman: National Congress of American Indians. Available online: http://www.ncai.org/attachments/PolicyPaper_ SpMCHTcjxRRjMEjDnPmesENPzjHTwhOlOWxlWOIWdSrykJuQggG_NCAI-WalkSoftly.pdf (accessed on 16 January 2018).

New Mexico Highlands University Institutional Factbook. 2016. Available online: https://www.nmhu.edu/ institutional-research/ (accessed on 1 November 2019).

Pyrch, Timothy, and Maria Teresa Castillo. 2001. The sights and sounds of Indigenous knowledge. In The Handbook of Action Research. Edited by Peter Reason and Hilary Bradbury. London: Sage Publications, pp. 379-85.

Reason, Peter, and Hilary Bradbury, eds. 2008. Sage Handbook of Action Research: Participative Inquiry and Practice, 2nd ed. London: Sage Publications.

Sankar, Meenakshi. 2005. Bridging the gap between policy, research and practice: Experiences from a community economic development action research project in New Zealand. Social Policy Journal of New Zealand 26: 52-65.

Schafft, Kai A., and Davyd J Greenwood. 2003. Promises and dilemmas of participation: Action research, search conference methodology, and community. Community Development 34: 18-35. [CrossRef]

Shor, Ira. 1996. When Students Have Power: Negotiating Authority in a Critical Pedagogy. Chicago: The University of Chicago Press.

Stroul, Beth A., and Robert M. Friedman. 1986. A System of Care for Severely Emotionally Disturbed Children and Youth. Washington, DC: CASSP Technical Assistance Center.

Substance Abuse and Mental Health Services Administration. Gathering of Native Americans (GONA) Curriculum. 2015. SAMHSA Publication No. HHSS280201300001C. Available online: https:/www.samhsa.gov/sites/ default/files/gona-goan-toolkit.pdf (accessed on 18 January 2018).

The Canadian Encyclopedia. 2019. Available online: https://www.thecanadianencyclopedia.ca/en/article/firstnations (accessed on 1 November 2019).

Tuckman, Bruce W. 1965. Developmental sequence in small groups. Psychological Bulletin 63: 384. [CrossRef] [PubMed]

Tuhawai-Smith, Linda. 1999. Decolonizing Methodologies: Research and Indigenous Peoples. New York: Zed Books, Ltd. 
U.S. Census Bureau. 2012. The American Indian and Alaska Native Population: 2010. Available online: https://www.census.gov/history/pdf/c2010br-10-112019.pdf (accessed on 1 November 2019).

Williams, Robert A., Jr. 1999. Linking Arms Together. New York: Routledge.

(C) 2020 by the authors. Licensee MDPI, Basel, Switzerland. This article is an open access article distributed under the terms and conditions of the Creative Commons Attribution (CC BY) license (http://creativecommons.org/licenses/by/4.0/). 